\title{
Pakistan-India Relations: An overview of Foreign Policy during Pervez Musharraf Regime
}

\author{
Afshan Iqbal \\ Research Scholar \\ Department of International Relations \\ Federal Urdu University of Arts, Sciences \& Technology \\ Karachi - Pakistan \\ afshaniqbal41@yahoo.com \\ $\&$ \\ Dr. Asghar Dashti \\ Incharge, Department of International Relations \\ Federal Urdu University of Arts, Sciences \& Technology \\ Karachi - Pakistan \\ masghardashti@gmail.com
}

\begin{abstract}
In this article, Pakistan-India relations are analysed with special reference to the era of Pervez Musharraf, regarding his foreign policy. In this article, all the key factors are highlighted and discussed involving the conflicts between the two nuclear powered arch-rivals. The Kashmir conflict is at the centre of all of them. When General Pervez Musharraf took military power in Pakistan, many problems arose, including those related to the economy and foreign policy towards its neighbour, particularly India. The war in Kargil was still hot and Musharraf had to deal with the situation. Before a policy towards India was defined and implemented to save the people of these regions from the destruction of a nuclear war, the situation deteriorated further after the September 11, 2001 attack on the United States. In September 2006, President Musharraf and Prime Minister Singh agreed to establish an Indo-Pakistani counter-terrorism institutional mechanism to identify and conduct counter-terrorism initiatives and
\end{abstract}




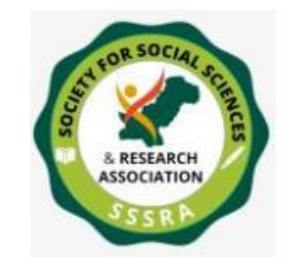

investigations. The 2007 attack on the Samjutha Express in India, which killed 68 civilians, most of them Pakistani, was also a key point in the relationship. This led to a major breakdown in relations between the two countries. More recently, in November 2008, terrorists attacked Mumbai, killing and injuring many people. Later, relations between the two countries were very tense. However, many efforts have been made in the history of the two rivals, and some of them have been very successful, but most of them were suddenly interrupted.

Keywords: Pakistan, India, Kashmir, United States, Kargil

\section{Introduction}

When British ruled out from the subcontinent in 1947, then Pakistan and India two autonomous nations appeared on the map of the world. Subsequent partition of the subcontinent evacuated millions of people from both sides and thousands of people killed during this immigration. Almost immediately both countries tried to establish political relationships, however, on behalf of their aggression division, they could not set up good relations. At the very beginning issue of partition of Punjab and Bengal, shaped many discomforts and set up the roots of uncertainty between two countries that are still prevailing and still hinder many opportunities to gain confidence for establishing a relationship. During the last sixty-five years, both countries have fought three big wars and some secret wars. Both countries have been involving in many equipped conflicts since 1947. The most important issue between Pakistan and India in the Kashmir conflict; due to this issue both rivalries have fought many wars and in 1971 Pakistan divided into two separate countries. Pakistan being at a very difficult stage has to face another event when after 3 months of 9/11; some terrorist attacks Indian parliament building in 2001. India instantly blamed Pakistan for this attack without through investigations and continues her policy to make the Pakistan government under pressure and to make the international community against her. India wants to make use of International Political situation and terrorism against Pakistan. She started to link terrorism activities to the religious parties of Pakistan. It was very difficult at that time to break the shackles. The tension between Pakistan and India turned to sever and rose to a high level after the Indian Parliament attack 


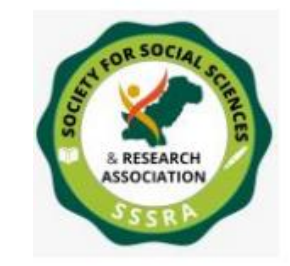

Pakistan-India Relations An overview ......

and both countries were at the bank of another war. Armies were at the borders. It was the worst situation across the Pak India border and LoC in Kashmir. During the Musharraf era, both governments took many steps to make normalize the relations definite CBMs like ceasefire agreement in November 2003 and bus service between Lahore and Delhi. These steps made the cause of deescalating the tension between Pakistan and India. In January 2004 composite dialogue between the two countries was initiated by both governments. It was a turning point between Pakistan and India relations during the Musharraf era. Both the leaders identified many issues, i.e., Jammu and Kashmir issue, Sir Creek issues, peace and security including CBMS, Waller barrage, terrorism and drug trafficking, to be discussed bilaterally between the Pakistan and India. Pakistan and India are nuclear weapons holding countries and many times in history are at the brink of nuclear war. Tensions between two nuclear bomb holding rivalry states not only concern to the people of the two countries but also to the people of the region and for the international community as well. Though a lot of efforts in history initiated to smooth the relations between two rivals and a few of them are very successful, but most of them are ended abruptly due to some reasons. Keeping because of the importance of the study we will limit to the period of the Musharraf regime. It will cover all aspects of the issue during that period and will also critically analyze the efforts, issues, treaties and Musharraf inclination towards the solution of the problems between two nuclear power rivals (Niaz, 2006)

\section{Review of the Literature}

There exists considerable literature on Pakistan and India relations but in context to Pervez Musharraf regime if it is not scarce, also not abundantly available. The following literature is readily available on the topic. The book by Gen. Pervez Musharraf, -In the Line of Fire: A Memoir (Musharraf, 2014), provide information about the early life of Pervez Musharraf as well as what he feels about the issues with India especially Kargil war. The full story of the events that brought President Musharraf to power in 1999 told for the first time in this book. However, it is an autobiography of Pervez Musharraf, but this book provides us with a lot of knowledge and information about the Kargil war. The book by Rafique Ahmad, Pakistan India relations: prospects for a durable peace (Ahmed,1989) provide comprehensive information regarding History on India Pakistan and South Asia as well as also discuss issues political freedom and security and international security. In this book, 


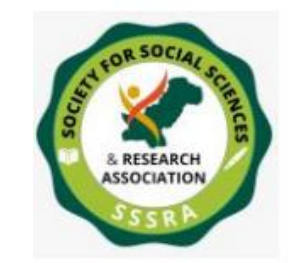

Pakistan-India Relations An overview ......

the writer says that how we can make peace in this region. He discusses all issues that can make causes to a bad situation in South Asia. The book by Ijaz Hussain, - Dimensions of Pakistan-India relations (Husain, 2006) provide reflections on the planned Pakistan India talks, the peace development and the surrealistic peace process. The book by Duncan McLeod, -India and Pakistan: Friends, Rivals or Enemies?(McLeod, 2008) Examine the politicization of culture, cultures of rivalry and conflict, enmity and unlimited conflict. The volume will appeal to students and scholars in the fields of political theory, Asian politics and political sociology. The book by Hamid H. Kizilbash and Khawar Mumtaz, -Pakistan foreign policy and the legislature (Kizilbash \& Mumtaz,1976) discuss comprehensively Pakistan foreign policy and Includes excerpts from the speeches of some noted point. The book by Ed. K.R. Gupta, -India-Pakistan Relations with Special Reference to Kashmir Volume 4 (Gupta , 2006) has brought out at a time when the bilateral relations between India and Pakistan are improving fast. This book presents a great study on the main issue of Kashmir between Pakistan and India. It tells us the main causes of this issue and gives suggestions about the issue. The book by Samin Khan, - Pakistan: ideology, Constitution, laws, foreign policy (Khan (1),1961) essays in Pakistan' Ideology, constitution, laws, foreign policy, which were for the most part originally published in Karachi newspapers in 1959-1973. It provides us with comprehension knowledge about ideology and constitution of Pakistan. It also discusses the foreign policy of Pakistan, especially with India. The book by Stanley A. Wolpert, -India and Pakistan: Continued Conflict or Cooperation? (Wolpert, 2010) Written with the benefit of deep knowledge of the region and informed by incisive and erudite analysis. Pakistan and India have many issues and conflicts that all issues are resolvable through negotiation. In this work, the writer discusses the continued issues and conflicts and gives some suggestions to resolve the current issue between both rivalries.

\section{Military Regime of Pervez Musharraf}

Pak army chief gen Pervez Musharraf took over the country by dismissing the democratic government of Prime Minister Nawaz Sharif on 12 October 1999. After coming into power Gen Musharraf Introduced a new word chief executive instead of adopting chief martial Law Administrator. After coming into power Gen Musharraf tried to show the positive image of Pakistan at the front of whole words. And also tried to resume the friendly 
relations with India. The military government took over in Pakistan was not welcomed by the Indian government because they thought that Musharraf was the mastermind of Kargil. India also blames Pakistan for the cross border terrorism. That is why India announced she will not attend the SAARC meeting. The Indian aggression created more tensions between both countries at that time. On the other hand, Pakistan remains evolved in the support of freedom fighter in Jammu and Kashmir. The conflicts between both reached once again at the highest point when in 1999 an Indian Aircraft was hijacked to Kandahar after taking off from Katmandu- (Khan (2),2010)

\section{Agra summit}

During 2000 Pakistan tried hard to convince India for the bilateral negotiations. Pakistan also accepted unilateral ceasefire from Indian side but Indian leadership did not respond. The deadlock broke in 2001 when Musharraf made a telephone call to Indian Prime Minister to show his sympathies during the disaster of the earthquake in Kutch and Gujarat. Pakistan also sent good relief to India for the victim of the earthquake in Kutch and Gujrat. Vajpayee sent an invitation to Musharraf for the visit of New Delhi for summit-level talks. Musharraf accepted this invitation and reached India. Both leaders met in the historical city of Agra. The four rounds of a talk held and discuss mutual issues. Pakistan argued that India should accept the conflict of Kashmir and India argued that Pakistan should takea step to stop the cross border terrorism. However, all discussions led towards the failure of the Agra summit. (Nazir,2004)

\section{Relations of Pakistan \& India after the incident of 9/11}

The United States of America was hit by the terrorist attacks on September 11, 2001, which changed the whole scenario of the world. The Us president decided to attack the Al-Qaida and ask direct help from Pakistan. Gen Musharraf accepted US demand. India got the opportunity to attach the Kashmir issue with this terrorist attack. After this Indian Parliament was hit by a terrorist. India blamed on two Pak terrorist organization and ISI. The diplomatic relation of both countries once again at the lowest point. At that time India showed his Military aggression and Musharraf replied with the statement if Indian troops moved just a single step across the border then the Pakistani army and the supporter of 
Pakistan will surround the Indian army and it would not be a conventional war. The International community condemned the nuclear and military aggression of both states. Bush played a significant role to defuse the tension. He made a telephone call to Vajpayee and Musharraf for reconciliation. On Jan 12, 2002, Musharraf took a big step to counter the International pressure; he banned the Lashkar-e-Taiba and Jaish-e-Mohammad (Talbot, 2014)

\section{The renewal of complex negotiation}

The History of India Pakistan relations has always full of tensions. After a long period of tensions, the ice broke between both states when in 2004 SSARC held in Islamabad. Both leaders met in this conference and announce the revival of composite dialogues. Indian leadership changed and new prime minister of India Manmohan Singh continued this process. Musharraf and Manmohan Singh met in New York for this revival. the agenda of composite dialogue deal with eight-core issues including, CBM, Jammu and Kashmir, Siachin, Wular Barrage, Sir Creek, terrorism, promotion of friendly exchange in various field. President Musharraf once again took the way of cricket diplomacy. Musharraf wanted to see the cricket match between India and Pakistan in India. He reached India this visit turned into a complete Indo-Pak summit. Both leaders agreed to open the train service between Manobo and Khokhrapar border. (Lodhi, 2011)

\section{Adoption of joint Anti-Terrorism Mechanism}

Indo-Pak relations always in full of tensions the relations went in a good direction. The bilateral negotiations going in smooth manners but suddenly the situation changed when Mumbai attack by Islamic militants group. But P.M Manmohan sings avoiding calling the name Pakistan. A Joint Mechanism for countering the globe terrorism adopted by Manmohan sing and Musharraf. Both countries decided to implement the Indo-Pak Antiterrorism Mechanism. (Jalazai(1),2006)

\section{Kashmir:Musharraf's4 point formula}


Musharraf made a four-point formula on Kashmir issue during an interview to the Indian news network. This formula included soft border in Kashmir, autonomy in every region of Kashmir, Demilitarization of all-region and A joint supervisory mechanism. The Indian leadership agreed to see this proposal. Both governments were in contact with the implementation of Musharraf proposal.

\section{Incident and aftermath of Samjhauta Express}

The situation suddenly turned into violence when a running bus between Pakistan and India Samjhauta express was targeted by the terrorist. People who killed in this attack most of them from Pakistan. The people who saw this incident also describe that they saw some hind speaks men just after the explosion. It happened when Pakistani foreign minister Khursheed Mahmud Kasuri had planned to visit India for negotiations. India blamed on Pakistani army and ISI to directly involved in this incident. However, Pakistan refused the entire allegation from the Indian side. Despite this attack, Pakistan and India reached an agreement of reducing the risk from accidents relating to nuclear weapons in 2007. The bilateral economic relations were improved. A significant agreement settled between both states to establish the branches of reserve bank of India in Pakistan and the branches of state bank of Pakistan in India. (Chalk,2013)

\section{- The age of Commotion (2001-2003)}

It was the fateful day when the US attacked Afghanistan under the garb of war on terror and the whole region as well as global politics changed altogether. Pakistan surrendered before the demand of becoming an ally of the West in this war on terror. India, with its strong diplomatic force, employed its options more prudently as compared to that of Pakistan. On December 13, 2001, Indian parliament came under attack and India lobby with the help of war-mongering media laid all the blame on Pakistan. Thus, it was the first step to designate Pakistan as a state sponsor of terrorism. In this era, the year of 2001 can be termed as "Year of Turmoil" due to the events happening in this year, which paved the way for relations of Indo-Pakistan in the next decade.

\section{- Eye to Eye Conflict: Operation Parakaram}




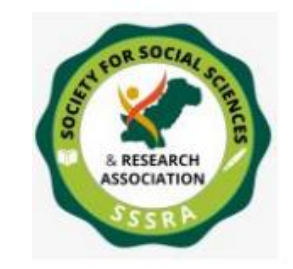

Pakistan-India Relations An overview ......

Following the terrorist attack on the Indian parliament, the Indian military started amassing its troops on the eastern border of Pakistan signalling a full-scale offensive. In response to the Indian aggressive posture, Pakistan shifted its forces from the western front to the eastern front. Consequently, a long-drawn army build-up was witnessed in South Asia when two nuclear-armed states were in war-gear. During the tense format of forces deployment, the western powers were quite concerned about the usage of nuclear weapons at the disposal of both nations. It is a matter of fact that the leaders from both sides of the divide were hurling provocative statements, which proved to be detrimental to the peace process in South Asia. The leading social scientists on the political and strategic landscape of the region believed that both nations lacked requisite acumen to handle the matter at their own. The Indian defence minister was becoming more critical of the policies of Pakistan with each passing day. It is also a matter of reality that India and Pakistan stalled back-channel diplomacy in the smoke of tensions at that time. This was high time when the West especially, the US felt concerned to intervene in the bilateral tensions of India and Pakistan.

\section{- The Way to Neutralised Strains: The Pressure of International Community}

The strained relations of India and Pakistan during the tricky time-period of the American war on terror in Afghanistan was seriously hampered due to the massive military stand-off between India and Pakistan. This is interesting to note that Pakistan and India didn't follow rational foreign policy options in resolving the long-standing issues between them. On several occasions, it was on the part of the modern world to step in and to handle the dispute in South Asia. The similar happened in the case of the 2001-2002 military stand-off. The Agra Summit, which held in July 2001 met with failure as the foreign ministers from both sides could not devise out an approved plan to be accepted by both hard-pitched adversaries. The neo-liberal theorists are of the view that monetary benefits and relations are key to resolve any long-standing issue between two or more than two adversaries. The history of international relations is replete with such examples where two hard enemies resolved the matters on the negotiation table after bloody wars. In the case of India-Pakistan equation, it was preferably interests of the West, which pressurized both nations to surrender their options of war. It is interesting to note that leading corporations working in India and Pakistan threatened to withdraw their business outlets from both warring nations, 


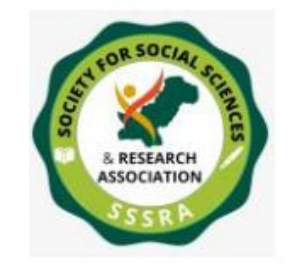

Pakistan-India Relations An overview ......

which led to the defusing of tensions. Also, it is a worth-mentioning reality that American engagement was more preponderant as compared to any other solution. On the other hand, the European Union also exerted its leverage in terms of blocking the imports mainly from India. The India leadership started thinking to withdraw from the hard-line position. The US was also pressurizing India to take its forces back to normal positions as Pakistan's armed forces were required on the western front to break-down the increasing operational capability of Taliban fighters. If the end of Operation Parakaram is summarized in a few words then it can safely be argued that international pressure was the key factor, which forced both of the nations to go back on their pre-escalation period. Sadly, the mutual mechanisms between India and Pakistan were not working at that stage.

\section{- To the Melting of Ice from Cold Start Doctrine (2004-2006)}

After the de-escalation of the border conflict in 2002, Pakistan and India witnessed a brief détente with India resorting to hard-line position again. Admittedly, India termed the failure of the Operation Parakaram back in 2002 as the major operational defeat of the Indian army in the larger context. Comparatively, Pakistan's armed forces were in high morale due to the operational mobility in a time of the war-like situation. The impartial observers on the security setup of India and Pakistan are of the view that it was due to the security dilemma between India and Pakistan, which blocked the prospects of peace between two countries. The security dilemma is due to the bitter historical experiences faced by both of the nations at the time of great divide back in 1947. Not only Pakistan, but India also sees the robust military structure of Pakistan as an offensive and India-centric approach. The security dilemma is the core reason behind the unending arms race between India and Pakistan. (Pervez,2013)

\section{- The Unfriendly Flinch of Pakistan-India Relations}

It was on 28 April 2004 when Indian Chief of Army Staff General Nirmal Chander unveiled the cold start doctrine, which was aimed at integrating Indian army offensive corps into 8 Integrated Battle Groups (IBGs) to punish Pakistan for subversive activities. However, the nuclear strategists in Pakistan opine that such an effort may lead to an all-out nuclear war between nuclear states. India's cold start doctrine proved to be a stumbling block in the 


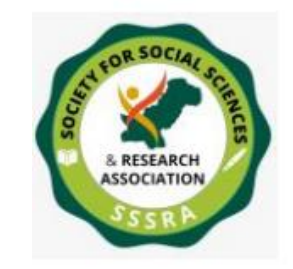

Pakistan-India Relations An overview ......

formation of cordial relations between two belligerent states. It has already been pointed out that Pakistan has been a security state since its inception due to the imminent securityrelated threats to its very existence from the Indian side. There were several occasions when negotiations between India and Pakistan met with failure and the core reason was enduring trust deficit between two states. It is a matter of reality that the emergence of the much-hyped cold start doctrine rang the alarm bells in GHQ, Rawalpindi. Pakistan started weighing-up its options to secure its national interest against a belligerent neighbour. In such an environment where security has got the top priority, the possibility of a peace process was diminished. It is a dilemma in the relations of both arch-rivals of South Asia that whenever peace-process gets its roots there emerges hawkish attitude on both sides of the border. With the de-escalation of the border tensions back in 2002, the India cold start was the hardest blow to the peace process in the region. Pakistan was engaged against the militancy in its tribal zone and the war on terror was on its full swing. At the same time, India was planning to steer the war on terror towards designate Pakistan a state sponsor of terrorism. Instead of making positive contributions in building a sustainable future for the region, the narrow approach on the part of the Indian policymakers brought the relations on the new low.

\section{- Start of CBMs}

In the tense atmosphere of distrust, the foreign pressure was forcing India and Pakistan to come on tables and resolve the matter following established Standard Operating Procedures (SOPs). Despite entrenched rivalry, Pakistan and India have some agreements, which were agreed upon by both of them and were respected to a certain extent. From Tashkent to the peace process in 2004, the rival states showed some restraint in the handling of issues. The first meeting to diffuse the tensions was held in June 2004 and the Pakistani delegation visited New Delhi. For a couple of days, the framework of action was agreed upon between the interacting parties. - Both India and Pakistan accepted each other's nuclear status, which was achieved in 1998 - Both nations agreed to reduce accidental or unauthorized use of nuclear weapons in a time of escalated turf. $\bullet$ Pakistan and India agreed to uplift and boost the mechanism of existing hotline of Director General Military Operations (DGMOs) of both sides to help reduce the risk of escalation of a conflict. • Both of the sides agreed to issue pre-notification of missile tests to each other, which was a major shift in the 


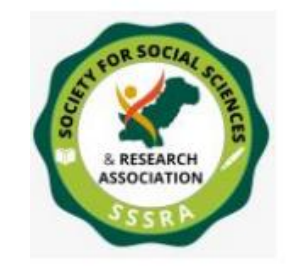

Pakistan-India Relations An overview ......

strategic policies of India and Pakistan. - Pakistan and India inched closer to initiate another round of talks after the first round-(Jalazai(2),2006)• Rounds of Talks and Resolution of Kashmir Issue through Back-Channel Diplomacy In December 2004, India and Pakistani delegations met for the second round of talks on the contentious issues pending between two nations. Kashmir has been a top agenda item in the talks and this was the reason Pakistan and India focused upon Kashmir, which is the bone of contention between them. There is an interesting aspect of these rounds of talks that Pakistan was under a dictatorship and India was being run by Bharatiya Janta Party (BJP), a hard-liner political party under the leadership of Mr Attal Bihari Vajpayee. For many political observers, it was an opportune time to settle the issue once for and all because the establishment in Pakistan is considered to be a real power, which calls the shots. On the other hand, the Congress government in India can never strike a deal with Pakistan without consent of the Hindu majority, which is being exploited by the BJP in the larger run. The backdoor diplomacy resulted in positive outcomes and the India-Pakistan equation agreed to move on to the third round of talks. During third round in 2005, both of states agreed to issue pre-notification of specialized ballistic missile tests before the conduction of tests. In 2006, the 4th round of talks took place between two nations. The analysts believe that the Kashmir issue was close to being resolved through back-channel diplomacy. Pakistan and India finalized a draft of resolving the Kashmir dispute with initiating the confidencebuilding measures at the helm of affairs. The draft included the articles mentioned below.

- Pakistan and India would grant relative autonomy to the Kashmir's and the option of the controlled self-rule be given to the valley of Kashmir $\bullet$ The armed forces of both countries would be disengaged as per the draft of the agreement $\bullet$ Both Indian held and Pakistan administered Kashmir parts have greater trade ties $\bullet$ Travel restrictions between two parts of Kashmir be relaxed If the draft of the agreement is analyzed with impartial lenses, it comes out clearly that a breakthrough was imminent. But, the irony is that whenever peace process comes to fruition, there appear obstacles in the way of those peacebuilding measures. (Amin 2000)

\section{- The period of Misperception:}

Although Pakistan and India made remarkable strides in the tense but rewarding period from 2004 to 2006 when a break-through was possible between two hostile and nuclear- 


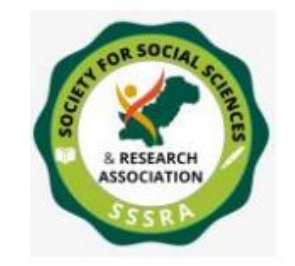

Pakistan-India Relations An overview ......

armed nations. The trust-deficit has made the India-Pakistan relations a hostage to just one nefarious incident, which can terminally hamper the peace process irrespective of its viability or vitality.

\section{- Peace Process Derailment and Samjhauta Express Event}

On 19th of February, 2007, the Samjhauta Express, train service between two states, was targeted by the nationalist Hindus with leaving 68 people dead. The blasts took place near Panipat, Haryana and Indian authorities feared that the bomb explosions were carried out by the Hindu extremists. To the utter dismay of the peace-mongers on both sides of the divide, the peace process hit the new low as the proposed draft about the resolution of Kashmir became the part of the dustbin. The Musharraf regime in Pakistan became busy in handling the resistance from the lawyer's movement. On the other hand, India started blaming Samjhauta Express incident on the Pakistan-based extremist organizations. (Jalazai(3),2006)

\section{- Mumbai Attack: The Hardest Blow to Peace Dialogues}

Pakistan and India have always been under the immense pressure from the hardliners in fomenting the hard-line positions in the respective countries. On November 26, 2008, the biggest terrorist attack in the Indian city of Mumbai shook South Asian peace environment. As expected, the Indian media fixed responsibility on the Pakistan-based organizations. It was the hardest blow to the peace efforts in the region. The extremist elements in India and Pakistan played their part in derailing the peace process in the long run. India along with its international propaganda put full blame on Pakistan and demanded the arrest of alleged mastermind, Hafiz Muhammad Saeed. Unfortunately, India provided no concrete evidence against the elements, which were claimed by India. Therefore, the matter became the bone of contention. India perceived that Pakistan is using terrorism as a tool of state policy. On actual terms, the situation was quite different. The doors of composite dialogue got closed as the trust-deficit was on its peak. Due to propaganda manoeuvring, the negative image projection of Pakistan alarmed the strategists in Islamabad. Subsequently, Islamabad devised out the policy of restraint in handling the affairs vis-à-vis India. The repeated terrorist attacks in Pakistan strengthened this idea that India is perpetrating the heinous 


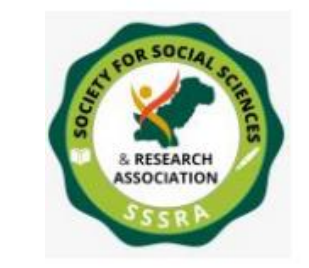

Pakistan-India Relations An overview ......

crimes in proxy warfare mechanism. Thus the prospects of rapprochement became bleak in this regard. The blame-game between India and Pakistan ensued with tit-for-tat style and the space for peace overtures shrunk with every passing day. (Sattar,2017)

\section{Conclusion}

Despite having the same culture, geographical and economical links both nations were failed to establish confidence and good relation with each other. Since their independence, the two countries have fought three major wars, one undeclared war and have involved in numerous armed conflicts and military dead heat. The Kashmir dispute is the main centrepoint of all of these conflicts. Both countries after confronting three major wars with each other from time to time, also involved in an armed race with each other. From the last twenty years, both governments were involved in improving their missile capabilities. Different types of missile tests conducted in both countries at different times in history. Both governments had become the major buyers of armed weapons from developed countries. Especially India had increased their defence budgets to a significant amount in recent history and source of interest for major weapons suppliers across the world USA, Germany, France, Italy etc. Tensions and war between India and Pakistan should take as an opportunity of a trade by major weapon supplier countries, who also dictate the world order and doctrine. Instead of expanding on education and trade government of both countries spend a huge amount of budget on armed race resulting in deprived nations on both sides. Due to the huge amount of defence budget and armed race with each other both countries failed to pay attention to the economic and educational development of their masses. People without proper education, skills and economic welfare falls prey to extremists and violence groups on both sides. Hatred against each other transferred from one generation to other without thinking its causes and impacts in future. This hatred against each other still transferred as an inherited gift from one generation to next in both countries. In 1998, both countries acquire the status of nuclear states after conducting nuclear tests subsequently to each other at the cost of well being of people of their countries. In 1999, both countries faced each other in the Kargil battlefield spoiling many precious lives from both sides. It was period just before the start of Gen. Pervez Musharraf regime in Pakistan. As the previous history, both countries were once again confronting each other, with the status of nuclear-capable states. Any mishandling or misconception of 


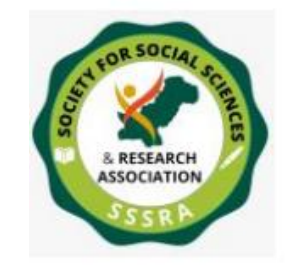

Pakistan-India Relations An overview ......

between two countries may turn the whole region into havoc. When Gen. Pervez Musharraf took rule in Pakistan as a military ruler, many problems were on the table including economy, foreign policy with its neighbour, especially towards India. When Musharraf came into power in Pakistan, the issue of Kargil war was still hot and Musharraf had to cope with it. Before establishing and exercising any policy towards India for preventing people of regions from the havoc of nuclear war, in future, the situation became worse with the attack of $9 / 11$ in the USA. After 9/11 terrorist attacks in the USA political scenario of the worlds changed at once. Al Qaida was alleged for these attacks hiding into Afghanistan. Pakistan being the neighbours of Afghanistan had geographical and strategically important for the war against terrorism. America wanted to launch a war against the Taliban from Pakistan soil. India rises to the occasion and wants to cash the situation. Indian government at the same time started to associate the freedom fighting movement of Kashmiri people as terrorist activities. Indian government tries its best to prove that Pakistan is a failed and irresponsible state. Indian government wanted to prove the international community that the Pakistan government was also supporting terrorist activities. At that very important juncture of history, India raised many questions of Pakistan role against terrorism and associated the freedom fighter movement of Kashmir to the terrorism act. She wants to streamline the freedom fighters movement in Kashmir with the act of terrorism. Musharraf government was thinking to find ways to cope with the international changing political scenario. Musharraf government was really in a fix to define its role in the war against terrorism by preventing its sovereignty and dignity. At the other side the Indian government, also want to take advantage of the war against terrorism. Indian government wanted to become front line alliance in the war against terrorism and ready to offer their soil, strategically services. They intended to launch war from Indian soil to Afghanistan through Pakistan. They want to curb Pakistan sovereignty by joining hands with the international community. Before Pakistan government devise any effective policy towards India and for international war against terrorism, a terrorist attack on the Indian parliament increased the difficulties for Musharraf government in Pakistan. Due to patience and better strategy from the Musharraf government, avoided from this war, and the situation tends to melt at the end of 2003. When the international community rejected any possibility to start a war against terrorism from Indian soil. Musharraf also involved to realize the international community for the impacts of war and exploits diplomatic and political resources to calm down the situation. After disappointing from international alliances when 


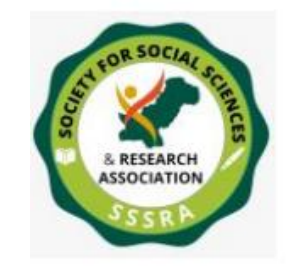

Pakistan-India Relations An overview ......

India feel that they had no role in the war against terrorism there was no chance except to start negotiations and remove its forces from Pakistan borders. Due to many diplomatic and political efforts of Musharraf government, the Indian government convinced to realize the importance of the dialogue process for amicable settlements of issues and differences including Kashmir. Leaders from both sides decided to adopt the policy of confidencebuilding measures between two rivalry countries. During the Musharraf era certain confidence-building measures — such as the 2003 ceasefire agreement and the DelhiLahore Bus service - were successful in deescalating tensions. However, these efforts have been impeded by periodic terrorist attacks. Due to patience and better strategy from the Musharraf government, avoided from this war, and the situation tends to melt at the end of 2003. When the international community rejected any possibility to start a war against terrorism from Indian soil. Pakistan and India have been trading since 1947 but they have not signed bilateral agreement. Despite all hurdles, India and Pakistan are two major trading partners among the South Asian countries. Many steps about trade have been taken by both governments in Musharraf era. If both countries act judiciously and understand the source of major conflict between the two nations, it is impossible to settle all differences and conflicts. They have to devise a policy to solve the major source of conflicts the Kashmir issues as early as possible and should not be played in the hands of others. By settling all outstanding issues including Kashmir we can stop transferring the inherited enmity between two countries to the next generation. If both countries succeed to establish good relation in future the region would be the world most prosperous and developed. Both countries now should think to invest in people and economic development rather than being involved in an armed race with each other. Now, it is the time, when leaders from both countries have to develop a strategy for the betterment of the people of the region. Musharraf regime can be a good source of inspiration for the present leader who started with a very difficult situation in the context of the relationship with India. Slow and steadily, he was successful in establishing the peace process with India. However, the peace process also suffered from terrorist activities from time to time but Leaders from both sides stick to the peace process. During 2003 to 2008 both countries were heavily engaged in settling all outstanding differences including the toughest and difficult issue of Kashmir. Kashmir was also at the agenda of the fourth level of composite dialogue in 2008 when terrorist again derail and sabotage the whole efforts and peace process. 


\section{References}

Ahmad, R. (1989). Pakistan India Relations: Prospects for a durable peace Lahore: Centre for South Asian Studies, University of the Punjab

Amin, S. (2000). Pakistan's Foreign Policy: A Reappraisal. London: Oxford University Press.

Chalk, P. (2013). Encyclopaedia of Terrorism (Vol. 1). Santa Barbara: : ABC-CLIO.

Gupta, E. K. (Ed.). (2006). India-Pakistan Relations with Special Reference to Kashmir (Vol. 4). New Delhi: Atlantic Publishers \& Dististributors.

Husain, I. (2006). Dimensions of Pakistan-India relations (Lahore: Heritage Publications)

Jalalzai, M. (2006) The Foreign Policy of Pakistan (Lahore: Publish in Lahore), 77-78

Jalalzai, M. (2006). Pakistan: Diplomacy, Islam and Foreign Policy (Lahore: Publish in Lahore), .83-84

Jalalzai, M. K. (2006). Pakistan: Diplomacy, Islam and Foreign Policy. (Lahore: publish in Lahore)

Kizilbash, H., \& Mumtaz, K. (1976). Pakistan foreign policy and the legislature (Lahore: South Asian Institute, University of the Punjab)

Khan, S. (1961). Pakistan: ideology, Constitution, laws, foreign policy (Karachi: Sentinel publications)

Khan, S. (2008). Nuclear Weapons and Conflict Transformation, [New York: Rutledge Publishers], p.119 
Lodhi, M. (2011) Pakistan Beyond The "Crisis State" [Karachi: Oxford University Press], 331-32

Musharraf, P. (2014). In the line of fire. New York: Simon and Schuster, Inc.:

McLeod, D. (2008). India and Pakistan: Friends, rivals or Enemies (Burlington (USA): Ash gate Publishing Company)

Niaz, A. (2006) Provincial Management Service Guide (Lahore: Jahangir Book Depot), 261-290

Nazir, M. (2004) The Political and strategic Dimensions in Indo-Pakistan Relations, volume.5, Number6, P.34

Pervez, S. (2013) Security Community in South Asia: India- Pakistan, [New York: Rutledge Publishers],

Sattar, A. (2017). Pakistan's Foreign Policy ;(Karachi: Oxford University Press), .307-8.

Talbot, I. (2014). Pakistan A New History [Karachi: Oxford University Press], 171-72

Wolpert, S. (2010) India and Pakistan: Continued Conflict or Cooperation (Landon: University of California Press) 